\title{
THE ORIGIN AND DEVELOPMENT OF THE TRADITION OF THE PASSION PLAY IN SRI LANKA
}

\author{
By
}

Father Anthony Fernandopulle

Ph.D.

2008 


\title{
THE ORIGIN AND DEVELOPMENT OF THE TRADITION OF THE PASSION PLAY IN SRI LANKA
}

\author{
By
}

Father Anthony Fernandopulle

Thesis submitted to the University of Sri Jayewardenepura for the award of the Degree of Doctor of Philosophy in Sinhala and Mass Communication on $18^{\text {th }}$ August 2008 


\section{Declaration of the candidate}

"The work described in this thesis was carried out by me under the supervision of Professor Tissa Kariyawasam and a report on this has not been submitted in whole or in part to any university or any other institution for another Degree/Diploma".

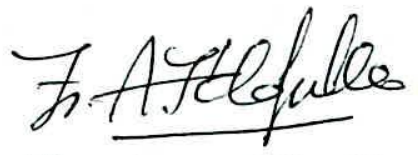

Signature of the Candidate
17.08 .2008

Date 
"I certify that the above statement made by the candidate is true and that this thesis is suitable for submission to the University for the purpose of evaluation".

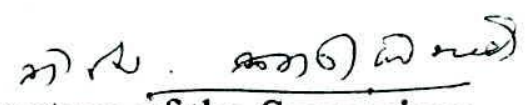

Signature of the Supervisor
Date $17 / 08 / 08$

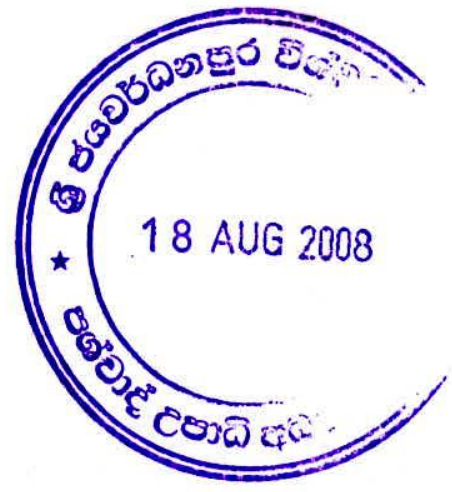




\section{TABLE OF CONTENTS}

Table of contents

p. i

Acknowledgements

p. iii

Abstract

p. v

Abbreviations

p. vii

Introduction

p. viii

1.01. The origin and development of the tradition of the Passion play and its development in Sri Lanka in Sri Lanka

p.1

1.02. The origin of liturgical drama

p.2

1.03. Paving the way for the development of religious drama

p. 3

1.04. Evolution of the Sinhala dramatic tradition in Sri Lanka

p.5

1.05. Different forms of plays performed in Sri Lanka

p. 8

1.06. Development of plays and the religious traditions

p. 9

1.07. The Christian contribution to Sinhala drama

p.11

1.08. Origin and development of dramatic performances

p. 12

1.09. Christian liturgical drama in India and Sri Lanka

p. 13

1.10. Origin of Portuguese liturgical

p. 16

1.11. Religious songs used in processions

p. 17

1.12. Nativity plays

p. 19

1.13. Passion plays

p. 21

2.01. The influence of Goa on Sri Lankan culture, politics and the Church

p. 23

2.02. The tradition of Passion play in Sri Lanka

p. 28

2.03. The roots of Christianity in Sri Lanka

p. 29

2.04. The implications of European politics on their colonies

p. 30

2.05. Paradigm shifts in the organization of the missions

p. 32

2.06. Fr. Jacome Gonsalves: a missionary from Goa.

p.37

2.07. Fr. Joseph Vaz the forerunner of Fr. Gonsalves

p. 42

2.08. Dramas performed by early missionaries and their literary contributions

2.09. The dramatic compositions of Jacome Gonsalves

p. 46

2.10. The structure and the dramatic elements of the Dukprapthi Prasangaya

p. 51

2.11. Nine sermons of the Dukprapthi Prasangaya

p. 55

2.12. Jacome Gonsalves the pioneer of the tradition of the Passion plays

p. 59

p. 68

3.01. Historical development of the Passion play tradition

p. 71

3.02. Importance of Goan Oratory in the Mission of Sri Lanka

p. 72

3.03. Religious freedom for Sri Lankan Catholics under the British Raj

p. 78

3.04. General Structure and content of Passion plays

p. 83

3.04.1. Dramatic scenes of cleansing the temple and cursing the fig tree

p. 89

3.04.2. Power struggle and conflict in the Passion plays

p. 94

3.04.3. Extravagant Love and exemplifying service

p. 98

3.04.4. Enduring the Cross

p. 102 
4. A Comparative study of the Passion plays of Boralessa and Oberammergau p. 127

4.01.Devotional and liturgical aspects of the Passion plays

4.02.K. Lawrence Perera and the Passion play

4.03.The Oberammergau Passion play

p. 137

4.03.1.The Black Death and the Vow

p. 139

4.03.2. Honouring the Vow

p. 141

4.04. A Comparative view of the Passion plays of Boralessa and Oberammergau

p. 144

4.05. Performance of Passion plays in different places

p. 174

4.05.1. The Passion play of Duwa

p. 175

4.05.2. The Passion play at Pitipana

p. 180

4.05.3. The Passion play at Maggona

p. 182

4.05.4. The Passion play at Kalaeliya

p. 184

4.05.5. The Kalamulla Passion play

p. 185

4.05.6. The Passion play at Pallansena

p. 185

Conclusion

p. 187

Bibliography

p. 190

Appendix

List of illustrations:

A photo of K. Lawrence Perera

p. 302

A picture of the Main Stage at Oberammergau

p. 303

A poster of the Boralessa Passion play

p. 304

A Passion play souvenir sent to the Vatican

p. 305 


\section{ACKNOWLEDGEMENT}

Many persons have helped and encouraged me in carrying out the research work and writing this thesis. First of all, I am thankful to my research supervisor, Professor Tissa Kariyawasam for his friendly guidance and wise counsel. His clear perception of theatre and dramatic tradition in Sri Lankan socio-religious realities helped me to develop a critical view of the Passion play tradition in Sri Lanka. I have benefited from the comments and suggestions made by Prof. Sunil Ariyaratna. I wish to make a special mention of Prof. Kumudu Wijewardana, the Dean of the Faculty of Graduate Studies for her valuable guidance and the keen interest she had shown in the progress of my research work. I also thank the Registrar, Deputy Registrar and the officers at the same Faculty for their friendly support I have received in all my dealings with the University.

I have to acknowledge my deepest obligations to several persons who have encouraged, aided me in this venture. With a deep sense of gratitude, I remember Archbishop, the Most Rev. Dr. Nicholas Marcus Fernando, who provided me with the opportunities and persuaded me to do all my religious and secular studies in the local Universities and my doctoral studies in the University of London. I also thank Fr. Anslem de Croos who has always encouraged me to do my postgraduate studies.

I express my thanks to those who, over the years, encouraged me to embark on, and to persevere in this task. I thank Prof. Ananda Abeysiriwardana who instilled in me a taste for literatures which subsequently led me to undertake this research work. I thank the Rector of the National Seminary, who gave me access to the library of the late Bishop 
Edmond Peiris. I thank the late Msgr. W.L.A. Don Peter who has gone out of his way to help me in carrying out my research work. This being a pioneering study on the Sri Lnakan Passion play tradition, I had to consult many scholars and historians who had some familiarity with the subject. My discussions with scholars such as Fr. Vito Perniola s.j., Fr. Quintus Perera and Fr. Aloy Pairis were an enlightening experience.

When I was making my study tours I was well received and given the necessary assistance at the Biblioteca da Ajuda in Lisbon close to the Tagus River. When I visited the Passion play village of Oberammergau without making any prior arrangements, I was offered hospitality and provided with the facilities I required by the Parish Priest of Oberammergau and I remember him with a sense of gratitude and appreciation. The days I spent at Oberammergau were unfortunately too short, but were very busy and fruitful. Since the area of my research work spread out in different places, I had to contact many people for fact finding. Whenever I approached someone I have received a welcoming response. I thank Fr. Blaise Cooray, former Parish Priest of Duwa who helped me to contact the prominent persons such as Solomon Joe Mihindukulasuriya, Sri Wa Lucas Fernando, Clement Fernando and Aloy Kotikawatta who were dealing with the Passion plays at Duwa and Pitipana. I also thank Fr. Jaya Rajah, who was the Parish Priest of Bolawatta who introduced me to the persons such as Anthony Fernando j.p. who were dealing with the Boralessa Passion play and took me to the K. Lawrence Perera Sri Dahara Cultural Centre. I also thank the relations of K. Lawrence Perera who with an added interest provided me with all the necessary information I was looking for my research work. Finally, I express my thanks to all those who have contributed in many ways in making this thesis a reality. 


\section{ABSTRACT \\ The origin and development of the tradition of the Passion play in Sri Lanka.}

The tradition of the Passion play has existed in Sri Lanka for over three centuries. Its origin or the root is not to be found in the island. Although liturgical drama was well established in their own country, it has not brought into the island by the Portuguese missionaries who came in to the country in the $16^{\text {th }}$ century. It was only during the Dutch period that the advent of the Passion plays to Sri Lanka took place. During that time the rich Passion play tradition that already existed in Europe came to Asia, particularly through the initiative of the Jesuit missionaries. Two prominent Oratorian missionaries who came to Sri Lanka from Goa, India were Frs. Joseph Vas and Jacome Gonsalves. They were students of St. Paul's Jesuit University and had the knowledge and the skill of the Passion plays. It was with them the tradition was inaugurated in Sri Lanka.

Fr. Jacome Gonsalves being a scholar and a skilful poet and a literary hero, he had composed the Dukprapthi Prasangaya and the Desana Navaye Pasan Pota which provided material for Passion plays carried out with statues. A critical study of these materials reveals that they have a sound theological and Biblical foundation in them. At the same time they constitute a form of popular devotion called para-liturgies. The Passion play and singing of pasan help them to experience the important events in the life of Jesus, such as his passion, death and resurrection. 
Subsequently, Passion plays were performed in different parts of Sri Lanka using the books of Fr. Gonsalves. They were read instead of dialogues, while statues were used for the characters of the play. During the liturgical season of Lent, which is a period of forty days from Ash Wednesday to Easter Sunday such pious exercises took a prominent place in Christian communities. K. Lawrence Perera's Passion play at Boralessa gave a new turn to the Passion play tradition by using live actors for the first time in 1923. As a talented dramatist and musician he employed new techniques in his Passion play. He had been to the world famous Oberammergau Passion play village in Germany and had taken the Oberammergau play as his model at Boralessa. A comparative study of these two Passion plays of Boralessa and Oberammergau reveals that.

The traditional Passion plays that existed in the island and the Boralessa Passion play paved the way for the spread of the same tradition elsewhere. Among them Duwa, Pitipana, Kalaeliya, Wadduwa, Halpe, Kandawala, Ja Ela, Kalamulla, Pallansena, Pamunugama, Wattala and Kandana Passion plays occupy a prominent place. 


\section{ABBREVIATIONS}

BAL : : Biblioteca da Ajuda, Lisbon

CALR : Ceylon Antiquary and Literary Register, Colombo.

cf. $\quad$ : compare

ed. $\quad$ : editor

edn. : edition

eds. $\quad$ : editors

ibid : Same page referred to

JCBRAS : Journal of the Ceylon Branch of the Royal Asiatic Society

Jn. : Gospel according to John

Lk. : Gospel according to Luke.

Mk. : Gospel according to Mark

Mt. : Gospel according to Matthew

no. $\quad$ number

NT : New Testament

op. cit. : : book referred to previously

OT. $\quad$ : Old Testament

p. $\quad$ : page

pp. : : pages

tr. $\quad$ : translation

vol. : volume

v. $\quad$ : verse

vv $\quad:$ verses 


\section{INTRODUCTION}

Christianity was brought to Sri Lanka in its Roman Catholic form and nurtured here under the protection of the Portuguese. This form of Christianity was persecuted under the Dutch conquerors who introduced the Dutch "Reformed" form, and then tolerated and later supported by the British. It has grown and spread in the island with a foreign character and an alien image. Today, more than 500 years after its 'implantation' in Sri Lanka, the Catholic Church is the largest Christian denomination in the country with a membership of over a million.

The Second Vatican Council (1962-1965) initiated the serious task of 'rediscovering the true image' of the Church vis-à-vis national contexts. The process of change was referred to as 'adaptation'. Later the notion of adaptation was broadened and more dynamic concepts were proposed, such as indigenization, inculturation, localization, contemporization and contextualisation. ${ }^{1}$ A striking feature in post-Vatican II ecclesiastical life and theology is the evolving process of indigenization. At different levels, efforts are made today to promote this process in the areas of liturgy, religious language and pious activities. Singing of pasan, carols and performance of Passion plays are such pious activities.

Much of the material available for this study is written in the Sinhala language; my thesis therefore, serves to make these Sinhala or Sri Lankan materials available to a wider English-language readership. All English-language quotations from the plays in this thesis are my

1. Buhlmann, W. The Coming of the Third Christ, Orbis Books, New York, 1978, p. 407. 
own translations from the Sinhala language. This body of translation is in itself a contribution: it makes the extraordinary range of Sinhala Passion plays such as the Passion play of Boralessa, accessible to the English-speaking world.

The tradition of the Passion play has existed in Sri Lanka for past few centuries. Yet a substantial analysis or comparative study has not been done on this subject. In addition to that I have a personal interest in this area of study. I am also aware that a conducive atmosphere has been created for this study through local and foreign schools of Passion plays. I am of the opinion that by using such sources available an in depth study could be carried out.

The methodology I have used for this study is research tours, interviews, literature surveys and manuscripts. The study tour I made to the Passion village of Oberammergau in Germany for this purpose was enlightening. The literature and the pictures I collected reveal the superb or unique quality of the Passion play. I have also interviewed the prominent people who actively participated and organized the Passion plays at Duwa, Pitipana, Boralessa, Pamunugama, Kandawala and Halpe. Most of the main actors of the above plays are still contributing to this tradition of Passion plays in their respective areas. I have in my possession the manuscripts of Boralessa and Kandawala Passion plays and aitach the former as an appendix to the thesis since $I$ have done a detailed comparative study of it with that of the script of Oberammergau Passion play. As far as the literary survey is concerned the relevant books 
in Sinhala and English are available to carry out the research work. The literary works of Fr. Jacome Gonsalves are of tremendous importance for the study since he is still hailed as the father of the Passion play tradition in Sri Lanka. All the Sinhala works of Fr. Jacome Gonsalves are well preserved in three volumes in the form of micro films in the Biblioteca da Ajuda Library in Lisbon. My visit to the same library in Portugal enabled me to complete my personal collection of his literary works. I have also easy access to the relevant books, magazines, articles and encyclopedia. However, I foresee certain limitations to the research such as limiting of Passion plays to certain areas and a particular period called the Christian liturgical season of Lent which is period of forty days or sometimes to the Holy Week which is a period of seven days beginning from Palm Sunday to Easter Sunday. Geographically, they are also limited to certain Western coastal maritime areas.

Most of the Christian literature and Passion plays are dedicated to depiction the life of Jesus Christ. Christians often recall the important events in the life of Jesus such as his birth, death and resurrection. The Christian liturgical calendar too is organized to commemorate these events in a cycle adding the Pentecost, the descent of the Holy Spirit, the centre of which is the outcome of the aforementioned events. The season of Advent is a preparatory period for Christmas, and Lent for the Passion, death and resurrection of Jesus. These unique events in his life have an effect on the lives of the faithful and create a culture. Undoubtedly, Christian liturgy, customs and feasts were major sources of the literature and the other arts of the West. During the season of Lent which is a period of forty 
days from Ash Wednesday to Palm Sunday, the tradition of Passion plays and singing of pasan are well established and popular in Sri Lanka. ${ }^{1}$ Passo or Pasku evolved from the Portuguese language. The Portuguese word passo $^{2}$ means a statue or a picture depicting the passion of Jesus.

Christian missionaries who came to Sri Lanka in the Portuguese period would have been familiar with religious drama of Portugal, Spain and other European countries. The autos ${ }^{3}$ or dramatic compositions of the Portuguese dramatist and poet Gil Vincente (1470-1536), and his Spanish counterpart, the prolific playwright, Lope de Vega (15621635), were certainly known to them. In fact, the fifteenth and sixteenth centuries were a period of great activity in Europe in the production of both religious and secular drama. The Mystery plays and Miracle plays, which originated in the liturgy of the Church and were first performed in the church itself, later drifted into the city squares and became so popular that special associations, the Comfreries, were formed to organize them. ${ }^{4}$ Some plays assumed enormous proportions both in regard to length and the size of the cast.

1. Ariyaratna, S. Karol, Pasan, Kantharu, Supasan Education service Publishers, Colombo, 1987, p. 111.

2. Pilendran, G. Tamil Catholic Literary Tradition of Sri Lanka, Luxsu Graphics, Colombo, 1998, p. 52.

3. Goonathileka, M.H. Sinhala Nadagam Ha Damila Kuththu, Volume I, S. Godage \& Brothers, Colombo, 1999, p. 31.

4. Ibid p.27. 